\title{
PENGARUH KINERJA SUMBER DAYA MANUSIA, KINERJA MANAJEMEN, DAN KINERJA PERMODALAN TERHADAP RETURN ON ASSET (STUDI KASUS PADA BANK UMUM SYARIAH 2011 - 2015)1)
}

\author{
Yeni Nor Fitriani \\ Mahasiswa Program Studi Ekonomi Islam-Fakultas Ekonomi dan Bisnis-Universitas Airlangga \\ Email: yeni.nor-12@feb.unair.ac.id
}

Dina Fitrisia Septiarini

Departemen Ekonomi Syariah-Fakultas Ekonomi dan Bisnis-Universitas Airlangga

Email: dina.fitrisia@feb.unair.ac.id

\begin{abstract}
:
The purpose of this study is to determine the effect of human resources, performance management, and performance of return on capital asset towards ROA. This study uses quantitative approach and the sampling technique used is purposive sampling. The samples used in this study are 10 BUSes. The analysis technique used is panel data regression. The results show that partially intellectual capital with iB-VAIC and the level of capital adequacy significantly affect the ROA, while the quality of GCG does not significantly affect ROA. Simultaneous research results show that intellectual capital with iB-VAIC, quality of GCG implementation and the level of capital adequacy significantly affect ROA. Therefore, the management of intellectual capital or resource management with a good knowledge and quality management of GCG supported by sufficient capital to support the operations of the company will be able to increase the ROA of sharia banks.
\end{abstract}

Keywords: Intellectual Capital iB-VAIC, Good Corporate Governance, Capital Adequacy Ratio, Return on Asset

\section{Pendahuluan}

\section{Latar Belakang}

Dewasa ini perkembangan industri perbankan di Indonesia semakin meningkat. Perkembangan di industri perbankan yang semakin meningkat ini mengakibatkan persaingan antar perusahaan semakin ketat. Dengan semakin ketatnya persaingan yang terjadi dalam industri perbankan, suatu bank dituntut untuk memiliki kinerja yang bagus dalam bersaing. Meningkatnya persaingan bisnis dewasa ini memacu manajemen untuk lebih memperhatikan dua hal penting yaitu keunggulan dan nilai. Penilaian atau pengukuran kinerja merupakan salah satu faktor yang penting dalam perusahaan. Dalam manajemen tradisional, ukuran kinerja yang biasa digunakan adalah ukuran keuangan, karena ukuran keuangan inilah yang dengan mudah dilakukan pengukurannya (Rivai, 2009: 686). Profitabilitas merupakan indikator yang paling tepat untuk mengukur kinerja suatu bank. Ukuran profitabilitas pada industri perbankan yang digunakan pada umumnya adalah $\begin{array}{llr}\text { Return on Asset (ROA). } & \text { Alasan } \\ \text { penggunaan variabel ROA dalam } \\ \text { penelitian ini adalah karena } & \text { ROA } \\ \text { berfungsi untuk mengukur kemampuan } \\ \text { manajemen dan efisiensi dalam } \\ \text { menggunakan aset perusahaan untuk } \\ \text { menghasilkan keuntungan }\end{array}$ 1] Jurnal ini merupakan bagian dari skripsi dari Yeni Nor Fitriani, NIM: 041211433083, yang diuji pada 26 Januari 2017 
Fitriani, et al/Jurnal Ekonomi Syariah Teori dan Terapan Vol. 4 No. 7 Juli 2017: 560-575; PENGARUH KINERJA SUMBER DAYA MANUSIA, KINERJA MANAJEMEN, DAN KINERJA PERMODALAN TERHADAP RETURN ON ASSET (STUDI KASUS PADA BANK UMUM SYARIAH 2011-2015)

melaporkan total pengembalian yang diperoleh untuk semua penyedia modal.

Perkembangan mengenai ROA bank umum syariah dan unit usaha syariah telah dijelaskan didalam tabel 1.

Tabel 1

Rasio Profitabilitas Bank Umum Syariah

\begin{tabular}{|c|c|c|c|c|c|}
\hline ROA & $\mathbf{2 0 1 1}$ & $\mathbf{2 0 1 2}$ & $\mathbf{2 0 1 3}$ & $\mathbf{2 0 1 4}$ & $\mathbf{2 0 1 5}$ \\
\cline { 2 - 6 } & 1,79 & 2,14 & 2,00 & 0,41 & 0,49 \\
\hline
\end{tabular}

Sumber : Statistik Perbankan Syariah (www.ojk.go.id) (diolah)

Dengan melihat kondisi ROA pada

tahun 2011 hingga tahun 2015 dan mengingat persaingan di dalam dunia bisnis dewasa ini yg semakin ketat, seharusnya bank syariah mampu mengubah cara mereka dalam menjalankan bisnisnya agar mampu meningkatkan ROA nya dari tahun ke tahun sehingga mampu untuk bersaing.

Globalisasi, inovasi teknologi dan persaingan yang ketat pada abad ini juga memaksa perusahaan-perusahaan mengubah cara mereka menjalankan bisnisnya. Agar dapat terus bertahan dengan cepat perusahaan-perusahaan mengubah dari bisnis yang didasarkan pada tenaga kerja (labor-based business) menuju knowledge based business (bisnis berdasarkan pengetahuan), dengan karakteristik utama ilmu pengetahuan. Seiring dengan perubahan ekonomi yang memiliki karakteristik ekonomi yang berbasis ilmu pengetahuan dengan penerapan manajemen pengetahuan (knowledge management) maka kemakmuran suatu perusahaan akan bergantung pada suatu penciptaan transformasi dan kapitalisasi dari pengetahuan itu sendiri (Sawarjuwono dan Kadir, 2003).

Pengetahuan merupakan sebuah potensi yang sangat penting bagi perusahaan dalam menghadapi persaingan yang semakin ketat. Pengetahuan juga mempunyai peran dalam meningkatkan kemampuan karyawannya dalam menghasilkan suatu inovasi yang baru dalam suatu perusahaan. Seorang pemimpin dan karyawan, semuanya membutuhkan pengetahuan untuk meningkatkan kinerja suatu perusahaan. Dalam Al-Qur'an telah dijelaskan mengenai seberapa pentingnya suatu pengetahuan tersebut, yang dijelaskan dalam QS. Al-'Alaq ayat 1-5:

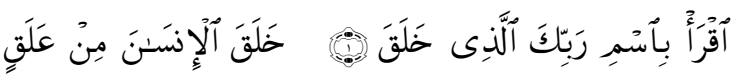

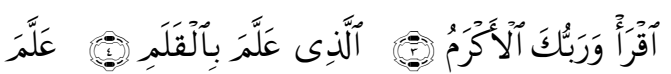<smiles>[Al]=C[As]=[W]</smiles>
Iqra' bismi rabbikalla zi khalaq (1) Khalaqal-insaña min alaq (2) Iqra' wa rabbukalakram (3) Allazi 'allama bil-qalam (4) 'allamal-insaña ma'lam ya'lam (5)

Artinya: "Bacalah dengan (menyebut) nama Tuhanmu yang Menciptakan (1) Dia Telah menciptakan manusia dari segumpal darah (2) Bacalah, dan Tuhanmulah yang Maha pemurah (3)yang mengajar (manusia) dengan perantaran kalam (4) Dia mengajar kepada manusia apa yang tidak diketahuinya (5) (Departemen Agama Rl, 2010: 597).

Perubahan dari ekonomi yang berbasis ilmu pengetahuan dengan penerapan manajemen pengetahuan memicu tumbuhnya minat dalam pengungkapan intellectual capital. Menurut Ståhle et al. (2011: 541), 
Fitriani, et al/Jurnal Ekonomi Syariah Teori dan Terapan Vol. 4 No. 7 Juli 2017: 560-575; PENGARUH KINERJA SUMBER DAYA MANUSIA, KINERJA MANAJEMEN, DAN KINERJA PERMODALAN TERHADAP RETURN ON ASSET (STUDI KASUS PADA BANK UMUM SYARIAH 2011-2015)

Intellectual capital (IC) adalah kajian penelitian baru yang mendapatkan perhatian cukup besar dari para ahli di berbagai disiplin seiring dengan pertumbuhan ekonomi yang berbasis serta mempu meningkatkan partisipasi masyarakat banyak sehingga menggalakkan usaha-usaha ekonomi rakyat dengan pertumbuhan ekonomi yang berbasis pada pengetahuan (knowledge-based economy).

Intellectual capital yang dikelola secara efisien akan menunjukkan bahwa perusahaan tersebut mampu mengelola sumber daya yang dimilikinya dengan baik. Pengelolaan sumberdaya yang baik akan menyebabkan peningkatan dari kemampuan karyawan. Peningkatan kemampuan karyawan inilah yang akan memberikan kontribusi kedalam perusahaan dalam peningkatan kinerja keuangan perusahaan dan akan berujung pada tercapainya keunggulan kompetitif bagi perusahaan.

Menurut Ulum (2013), model pengukuran kinerja IC untuk perbankan syariah iB-VAIC yang merupakan modifikasi dari model yang dikembangkan oleh Pulic ini menjadi penting untuk dihasilkan setidaknya karena, penelitian di berbagai negara termasuk di Indonesia, menunjukkan bahwa IC memiliki peran dalam menggerakkan nilai perusahaan (firm's value).

Selain itu kinerja suatu entitas bisnis maupun manajemen bisnis pada saat ini tidak hanya diukur dari aspek keuangan saja. Tanggung jawab keuangan yang ditampakkan dalam ukuran moneter, akuntansi maupun rasio-rasio tertentu juga harus dilengkapi dengan kinerja nonkeuangan seperti penerapan kualitas GCG. Kualitas penerapan GCG merupakan mekanisme pengendalian kegiatan operasi agar berjalan dengan benar dan sesuai mekanisme perusahaan.

Menurut Ekowati, dkk. (2012), tidak hanya modal fisik yang berperan dalam penciptaan nilai dalam perusahaan, modal finansial sebagai sumber pendanaan perusahaan juga memiliki peran yang penting bagi keberlangsungan perusahaan. Menurut Yuliana (2015), bagi industri perbankan, permodalan merupakan suatu hal yang sangat penting, bank harus mampu menjaga kepercayaan nasabah dengan memiliki modal yang mencukupi bagi kegiatan operasional sehari-hari. Tingkat kecukupan modal dalam penelitian ini diukur dengan menggunakan CAR.

Jika bank mengelola pengetahuan dengan baik dapat menigkatkan kemampuan karyawan dalam menerapkan tata kelola dengan baik, kemampuan ini lah juga yang dapat meningkatkan kemampuan karyawan dalam memenuhi kewajiban modal minimum. Berdasarkan uraian yang telah dijelaskan diatas maka peneliti tertarik untuk mengajukan penelitian tentang: "Pengaruh Kinerja Sumber Daya Manusia, Kinerja Manajemen, Dan Permodalan Terhadap ROA (Studi Kasus Pada Bank Umum Syariah Periode 201 1-2015)

\section{Tinjauan Pustaka}


Fitriani, et al/Jurnal Ekonomi Syariah Teori dan Terapan Vol. 4 No. 7 Juli 2017: 560-575; PENGARUH KINERJA SUMBER DAYA MANUSIA, KINERJA MANAJEMEN, DAN KINERJA PERMODALAN TERHADAP RETURN ON ASSET (STUDI KASUS PADA BANK UMUM SYARIAH 2011-2015)

\section{Bank Syariah}

Bank syariah merupakan bank yang secara operasional berbeda dengan bank konvensional. Salah satu ciri khas bank syariah yaitu tidak menerima atau membebani bunga kepada nasabah, akan tetapi menerima atau membebankan bagi hasil serta imbalan lain sesuai dengan akad-akad yang di perjanjikan. Konsep dasar bank syariah didasarkan pada Al-Qur'an dan hadits. Semua produk dan jasa yang ditawarkan tidak boleh bertentangan dengan isi AlQur'an dan hadits Rasulullah SAW (Ismail, 2011: 29).

\section{Stakeholder Theory}

Dalam konteks untuk menjelaskan tentang konsep IC, teori stakeholders harus dipandang dari kedua bidangnya, baik bidang etika (moral) maupun bidang manajerial. Bidang etika berargumen bahwa seluruh stakeholder memiliki hak untuk diperlakukan secara adil oleh organisasi, dan manajer harus mengelola organisasi untuk kepentingan seluruh stakeholder (Deegan, 2004 dalam Ulum, 2009: 5\&6). Dalam konteks hubungan IC dengan kinerja keuangan, teori stakeholder lebih tepat digunakan sebagai basis utama untuk menjelaskan hubungan IC dengan kinerja perusahaan. Dalam pandangan teori stakeholder, perusahaan memiliki stakeholders, bukan sekedar shareholder (Riahi-Belkaoui, 2003 dalam Ulum, 2009: 8).
Menurut Resource-Based Theory, IC memenuhi kriteria-kriteria sebagai sumber daya yang unik untuk menciptakan keunggulan kompetitif bagi perusahaan dengan menciptakan value added. Value added ini berupa kinerja yang semakin baik di perusahaan (Penrose, 1995 dalam Marfuah dan Ulfa, 2014).

\section{Intellectual Capital}

Menurut Sawarjuwono dan Kadir (2003), IC merupakan jumlah dari apa yang dihasilkan oleh tiga elemen utama organisasi (human capital, structural capital, customer capital) yang berkaitan dengan pengetahuan dan teknologi yang dapat memberikan nilai lebih bagi perusahaan berupa keunggulan bersaing organisasi.

Seringkali, istilah intellectual capital diperlakukan sebagai sinonim dari intangible assets. Meskipun demikian, definisi yang diajukan OECD, menyajikan cukup perbedaan dengan meletakkan intellectual capital sebagai bagian terpisah dari dasar penetapan intangible asset secara keseluruhan suatu perusahaan. Dengan demikian, terdapat item-item intangible asset yang secara logika tidak membentuk bagian dari intellectual capital suatu perusahaan. Salah satunya adalah reputasi perusahaan. Reputasi perusahaan mungkin merupakan hasil sampingan (atau suatu akibat) dari penggunaan IC secara bijak dalam perusahaan, tapi itu bukan merupakan bagian dari intellectual capital (Ulum, 2009: 21).

\section{Resource Based Theory}


Fitriani, et al/Jurnal Ekonomi Syariah Teori dan Terapan Vol. 4 No. 7 Juli 2017: 560-575; PENGARUH KINERJA SUMBER DAYA MANUSIA, KINERJA MANAJEMEN, DAN KINERJA PERMODALAN TERHADAP RETURN ON ASSET (STUDI KASUS PADA BANK UMUM SYARIAH 2011-2015)

iB-VAIC (Islamic Banking Value Added Intellectual Coefficient)

Dalam penelitiannya, Ulum (2013) memformulasikan model penilaian kinerja IC untuk perbankan syariah ini (yang akan diberi nama iB-VAIC dibaca Islamic Banking Value Added Intellectual Coefficient penting untuk dihasilkan sebagai modifikasi dari model yang telah ada, yaitu VAIC (Value Added Intellectual Coefficient). VAIC didesain untuk mengukur kinerja intellectual capital perusahaan-perusahaan dengan jenis transaksi yang umum. Sementara perbankan syariah memiliki jenis transaksinya sendiri yang relatif berbeda dari perbankan umum atau konvensional. Berikut tiga rumus yang digunakan dalam menghitung iB-VAIC yaitu:

Tahapan pertama, menghitung Islamic Banking Valve Added (iB-VA). iBVA dihitung sebagai selisih antara output dan input.

iB-VA= OUT-IN

Keterangan:

OUT (Output) : Total pendapatan, diperoleh dari:

Pendapatan bersih kegiatan syariah = pendapatan operasi utama kegiatan syariah + pendapatan operasional lainnya - hak pihak ketiga atas bagi hasil dan dana syirkah temporer.

IN (Input) : Seluruh beban (kecuali beban karyawan)

Tahap kedua, menghitung Islamic Banking Value Added Capital Employed (iB-VACA). Rumus yang digunakan adalah: $i B-V A C A=\frac{i B-V A}{C E}$

Keterangan:

CE : Capital Employed : dana yang tersedia (total ekuitas)

Tahap ketiga, menghitung Is/amic

Banking Value Added Human Capital (iBVAHU).

$\mathrm{iB}-\mathrm{VAHU}=\frac{\mathrm{iB}-\mathrm{VA}_{\mathrm{A}}}{\mathrm{HC}}$

Keterangan:

HC : Human capital : beban karyawan

Tahap keempat, menghitung Islamic Banking Structural Capital Value Added (iB-STVA).

$\mathrm{iB}-\mathrm{STVA}=\frac{S C}{i B-V A}$.

Keterangan:

SC : Structural Capital : iB-VA - HC

Tahap kelima, menghitung iB-VAIC (Islamic Banking Value Added Intellectual Coefficient).

$i B-V A I C=i B-V A C A+i B-V A H U+i B-$ STVA.

Kamath dalam Ulum (2009: 92) mengelompokkan kinerja bank berdasarkan IC ke dalam empat kategori, yaitu:

Tabel 2 Kategori VAIC ${ }^{\mathrm{TM}}$

\begin{tabular}{|c|l|}
\hline Nilai VAIC & \multicolumn{1}{|c|}{ Kategori } \\
\hline$>3$ & Top performers \\
\hline $2.00-2.99$ & Good Performers \\
\hline $1.50-1.99$ & Common Performers \\
\hline$<1.5$ & Bad Performers \\
\hline
\end{tabular}
Sumber: Ulum (2013)

\section{Good Corporate Governance (GCG)}

Definisi tentang GCG yang tercantum dalam Peraturan Bank Indonesia (PBI) No. 11/33/PBI/2009 mendefinisikan GCG sebagai suatu tata 
Fitriani, et al/Jurnal Ekonomi Syariah Teori dan Terapan Vol. 4 No. 7 Juli 2017: 560-575; PENGARUH KINERJA SUMBER DAYA MANUSIA, KINERJA MANAJEMEN, DAN KINERJA PERMODALAN TERHADAP RETURN ON ASSET (STUDI KASUS PADA BANK UMUM SYARIAH 2011-2015)

kelola bank yang menerapkan prinsipprinsip keterbukaan (transparency), akuntabilitas (accountability), pertanggung jawaban (responsibility), profesinoal (professional), dan kewajiban (fairness).

\section{Islamic Corporate Governance}

Menurut Muneeza dan Rusni (2014) dalam penelitiannya, menjelaskan definisi dari shari'ah corporate governance atau yang biasa disebut dengan islamic corporate governance, yang berarti:

"Shari'ah corporate governance is the Islamic version of corporate governance. This is the simplest way to explain what Shari'ah corporate governance is"

Maksud dari definisi yang telah dijelaskan di atas adalah, shari'ah corporate governance atau tata kelola perusahaan Shari'ah adalah tata kelola perusahaan dalam versi Islam. Ini adalah cara paling sederhana untuk menjelaskan apa itu Shari'ah corporate governance.

\section{Kecukupan Modal Bank}

Kecukupan modal merupakan hal penting dalam bisnis perbankan. Bank yang memiliki tingkat kecukupan modal baik menunjukkan indikator sebagai bank yang sehat. Sebab kecukupan modal bank menunjukkan keadaannya yang dinyatakan dengan suatu ratio tertentu yang disebut ratio kecukupan modal atau Capital Adequacy Ratio (CAR).

\section{Kinerja Keuangan Bank Umum Syariah}

Dalam manajemen tradisional, ukuran kinerja yang biasa digunakan adalah ukuran keuangan, karena ukuran kevangan inilah yang dengan mudah dilakukan pengukurannya. Profitabilitas merupakan indikator yang paling tepat untuk mengukur kinerja suatu bank. Ukuran profitabilitas pada industri perbankan yang digunakan pada umumnya adalah Return on Asset (ROA) (Rivai, 2009: 686).

\section{Model Analisis}

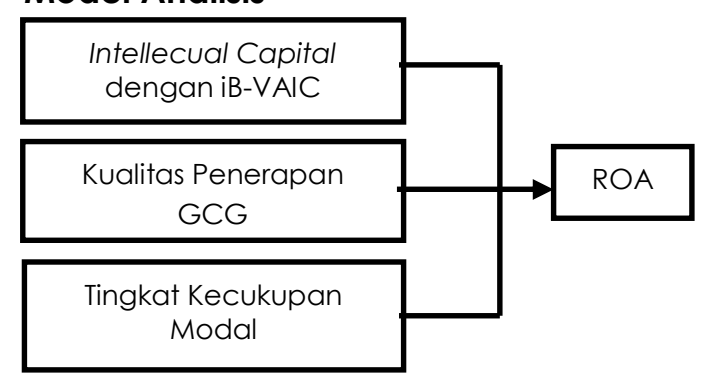

Sumber: Berbagai sumber, diolah.

\section{Gambar 1}

Model Analisis

Berdasarkan penjelasan di atas maka dapat dibuat persamaan regresi:

$Y=a+b_{1} X_{1}+b_{2} X_{z}+b_{3} X_{3}$

\section{Kerangka Berpikir}

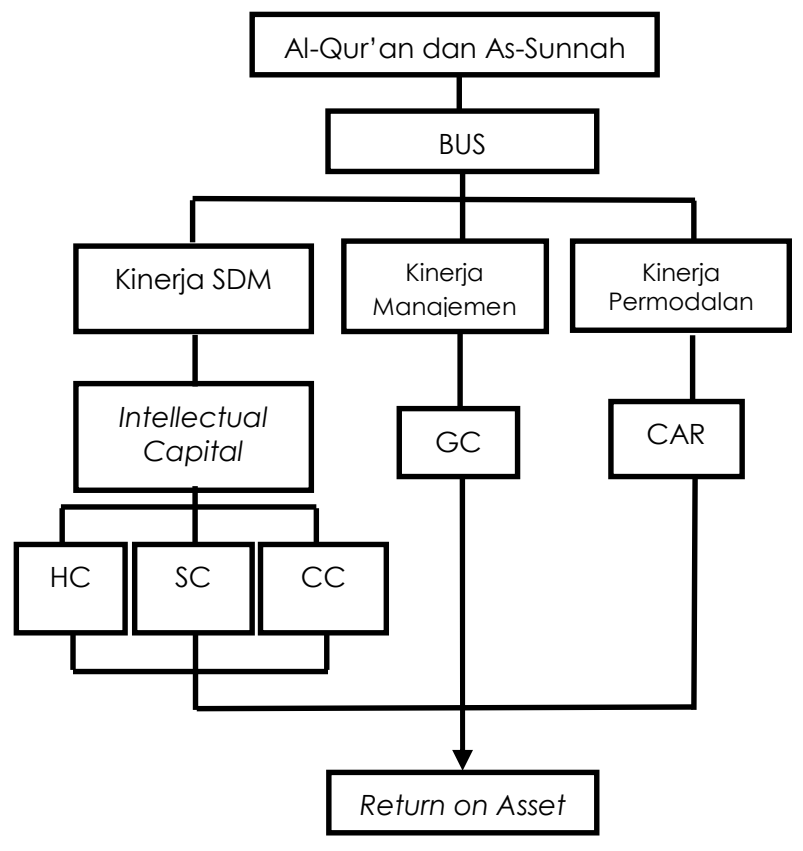

Gambar 2

III. Metode Penelitian

Kerangka Berpikir

\section{Pendekatan Penelitian}

Penelitian ini dilakukan dengan pendekatan kuantitatif dimana data 
Fitriani, et al/Jurnal Ekonomi Syariah Teori dan Terapan Vol. 4 No. 7 Juli 2017: 560-575; PENGARUH KINERJA SUMBER DAYA MANUSIA, KINERJA MANAJEMEN, DAN KINERJA PERMODALAN TERHADAP RETURN ON ASSET (STUDI KASUS PADA BANK UMUM SYARIAH 2011-2015)

penelitian berupa angka-angka dan dianalisis menggunakan alat statistik.

\section{Identifikasi Variabel}

Berdasarkan hipotesis dan model analisis, maka variabel dalam penelitian ini terdiri atas variabel independen dalam penelitian ini adalah intellectual capital dengan iB-VAIC $\left(X_{1}\right)$, kualitas penerapan GCG $\left(X_{2}\right)$, dan tingkat kecukupan modal $\left(X_{3}\right)$. Variabel dependen dalam penelitian ini adalah Return on Asset ( $Y$ ).

\section{Definisi Opersional}

\section{Intellectual Capital dengan iB-VAIC ( $\left.X_{1}\right)$}

Intellectual capital merupakan jumlah dari apa yang dihasilkan oleh tiga elemen utama organisasi (human capital, structural capital, customer capital) yang berkaitan dengan pengetahuan dan teknologi yang dapat memberikan nilai lebih bagi perusahaan berupa keunggulan bersaing organisasi (Sawarjuwono dan Kadir, 2003). Data intellectual capital yang digunakan dalam penelitian ini diambil dari laporan kevangan tahunan yang berupa annual report perusahaan Bank Umum Syariah (BUS) periode 2011 hingga 2015. Yang mana indikatornya berupa output, total input, total ekuitas, dan beban karyawan yang digunakan dalam perhitungan kinerja Intellectual Capital (IC) berupa rasio iB-VAIC IIslamic Banking Value Added Intellectual Coefficient).

\section{Kualitas Penerapan GCG ( $\left.\mathrm{X}_{2}\right)$}

Kualitas

$$
\text { penerapan }
$$

Good Corporate Governance (GCG) adalah sejauh mana bank menjalankan peraturan yang telah ditetapkan oleh BI tentang GCG. Pengukuran ini dengan menggunakan nilai komposit peringkat kualitas penerapan GCG bank yang berdasarkan kesesuaian pelaksanaan aspek GCG oleh bank dengan melaksanakan faktor-faktor penilaian yang telah ditetapkan oleh Bank Indonesia.

\section{Tingkat Kecukupan Modal $\left(\mathrm{X}_{3}\right)$}

Menurut Muhammad (2004: 214), kecukupan modal merupakan hal yang sangat penting dalam bisnis perbankan. Bank yang memiliki tingkat kecukupan modal yang baik menunjukkan indikator sebagai bank yang sehat. Sebab kecukupan modal bank menunjukkan keadaannya yang dinyatakan dengan suatu ratio tertentu yang disebut ratio kecukupan modal atau Capital Adequacy Ratio(CAR).

Tingkat kecukupan modal dalam penelitian ini dipresentasikan dengan Capital Adequacy Ratio (CAR). Data Capital Adequacy Ratio (CAR) yang digunakan merupakan data rasio yang diambil dari laporan tahunan perusahaan Bank Umum Syariah periode 201 1-2015.

\section{Return on Asset ( $\mathrm{Y}$ )}

Return on Asset (ROA) merupakan salah satu indikator keberhasilan suatu perusahaan dalam menghasilkan sebuah laba. Sehingga semakin tinggi profitabilitas maka semakin tinggi kemampuan perusahaan dalam menghasilkan sebuah laba. Data Return on Asset (ROA) yang digunakan merupakan data rasio yang diambil dari laporan tahunan perusahaan 
Fitriani, et al/Jurnal Ekonomi Syariah Teori dan Terapan Vol. 4 No. 7 Juli 2017: 560-575; PENGARUH KINERJA SUMBER DAYA MANUSIA, KINERJA MANAJEMEN, DAN KINERJA PERMODALAN TERHADAP RETURN ON ASSET (STUDI KASUS PADA BANK UMUM SYARIAH 2011-2015)

Bank Umum Syariah periode 2011 hingga 2015.

\section{Jenis dan Sumber Data}

Jenis data yang digunakan dalam penelitian ini adalah data sekunder. Sumber data berasal dari laporan tahunan yang dimulai dari tahun 2011 hingga tahun 2015 yang telah dipublikasikan di website masing-masing bank. Menggunakan populasi bank umum syariah dan menggunakan sampel dengan teknik purposive sampling. Sehingga terdapat 10 bank umum syariah.

\section{Populasi dan Sampel}

Populasi penelitian ini adalah seluruh Bank Umum Syariah di Indonesia. Setelah dilakukan teknik pengambilan sampel dengan menggunakan teknik purposive sampling maka sampel dalam penelitian ini terdapat 10 bank umum syariah yang memnuhi kriteria dalam penelitian ini.

\section{Teknik Analisis}

Teknik analisis data yang digunakan dalam penelitian ini adalah model analisis regresi data panel. Model analisis regresi data panel merupakan kombinasi dari data time series dan crosssection. Uji hipotesis meliputi uji $\dagger$ dan uji $F$ dan koifisien determinasi. Penelitian ini menggunakan tingkat signifikansi sebesar $(0,05)$ dan seluruh data diolah dengan Eviews 8.

\section{Hasil dan Pembahasan}

\section{Pemilihan Model Estimasi Data Panel}

Langkah-langkah yang dilakukan dalam mendapatkan model yang tepat dalam pemilihan estimasi regresi data panel adalah dilakukan Uji Chow Test dan Uji Hausman Test.

Tabel 3

Uji Chow

\begin{tabular}{lrrr}
\hline \hline Effects Test & Statistic & d.f. & Prob. \\
\hline \hline Cross-section F & 9.288185 & $(9,37)$ & 0.0000 \\
Cross-section Chi-square & 59.075444 & 9 & 0.0000 \\
\hline \hline \multicolumn{4}{c}{ Sumber: Eviews 8 } \\
\end{tabular}

Berdasarkan tabel 3 diperoleh nilai probabilitas (Cross-section F) sebesar 0,0000 yang berarti nilai probabilitas (Cross-section F) lebih kecil dari a $(0,05)$ sehingga $\mathrm{H}_{0}$ ditolak dan $\mathrm{H}_{1}$ diterima, dapat disimpulkan bahwa model sementara yang terbaik untuk digunakan yaitu model Fixed Effect Model (FEM) dibandingkan dengan Pooled Least Square/Common Effect Model (CEM).

Tabel 4

Uji Hausman

\begin{tabular}{lcrc}
\hline \hline Test Summary & Chi-Sq. Statistic Chi-Sq. df. & Prob. \\
\hline \hline Cross-section random & 57.387396 & 3 & 0.0000 \\
\hline \hline \multicolumn{4}{c}{ Sumber: Eviews 8} \\
Berdasarkan tabel 4 diperoleh nilai
\end{tabular}

Probabilitas (Cross-section random) sebesar 0,0000 yang berarti lebih kecil dari a $(0,05)$ sehingga $H_{0}$ ditolak dan $\mathrm{H}_{1}$ diterima, dapat disimpulkan bahwa Fixed Effect Model (FEM) merupakan model yang terbaik untuk digunakan dibandingkan dengan Random Effect Model (REM).

Berdasarkan hasil pengujian pemilihan model data panel diatas, maka dapat diambil kesimpulan bahwa metode analisis yang paling tepat untuk menganalisis data panel dalam penelitian ini adalah Fixed Effect Model (FEM). Hasil dari Fixed Effect Model (FEM) dapat djelaskan dalam tabel 5. 
Tabel 5

Hasil Estimasi Fixed Effect Model (FEM)

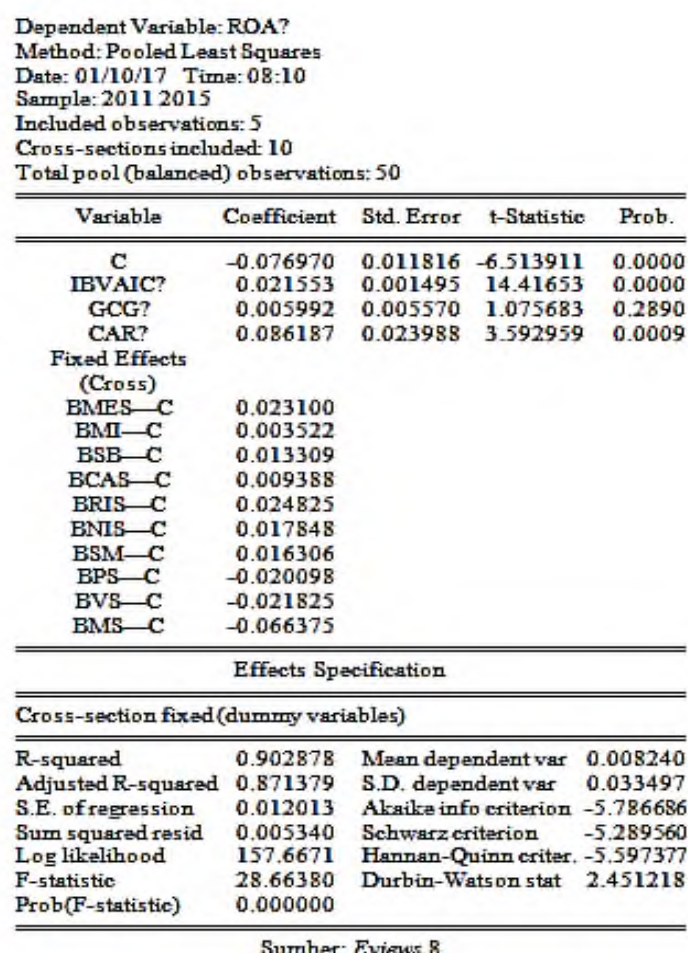

Berdasarkan hasil estimasi pada tabel 5 dapat ditulis bentuk persamaan liniernya sebagai berikut:

$\mathrm{ROA}=-0,076970+0,021553 \mathrm{IBVAIC}+$ $0,005992 \mathrm{GCG}+0,000862 \mathrm{CAR}$

Berdasarkan persamaan 7 maka hubungan antar variabel independen dan variabel dependen dapat ditunjukkan sebagai berikut:

1. Apabila seluruh variabel independen tidak mengalami perubahan konstan, maka Return on Asset (ROA) sebesar 0,076970 .

2. Apabila variabel iB-VAIC mengalami peningkatan sebesar satu satuan sedangkan variabel independen lainnya dianggap konstan, maka Return on Asset (ROA) akan mengalami peningkatan sebesar 0,021553 satuan.
3. Apabila variabel GCG mengalami penurunan sebesar satu satuan sedangkan variabel independen lainnya dianggap konstan, maka Return on Asset (ROA) akan mengalami peningkatan sebesar 0,005992 satuan.

4. Apabila variabel CAR mengalami peningkatan sebesar satu satuan sedangkan variabel independen lainnya dianggap konstan, maka Return on Asset (ROA) akan mengalami peningkatan sebesar 0,000862 satuan.

\section{Uji † (Parsial)}

Berdasarkan pengujian terhadap hipotesis pengaruh masing-masing variabel independen terhadap variabel dependen dapat dijelaskan sebagai berikut:

1. Variabel iB-VAIC memiliki t-statistic sebesar 14,41653 dengan tingkat probabilitas sebesar 0,0000 yang berarti lebih kecil daria $(0,05)$, sehingga Holditolak. Kesimpulan yang dapat diperoleh adalah variabel iB-VAIC berpengaruh signifikan secara parsial terhadap ROA pada bank umum syariah periode 2011-2015.

2. Variabel Kualitas Penerapan GCG memiliki t-statistic sebesar 1,075683 dengan tingkat probabilitas sebesar 0,2890 yang lebih besar dari a $(0,05)$, sehingga $\mathrm{H}_{02}$ diterima. Kesimpulan yang dapat diperoleh adalah variabel kualitas penerapan GCG tidak berpengaruh signifikan secara parsial 
Fitriani, et al/Jurnal Ekonomi Syariah Teori dan Terapan Vol. 4 No. 7 Juli 2017: 560-575; PENGARUH KINERJA SUMBER DAYA MANUSIA, KINERJA MANAJEMEN, DAN KINERJA PERMODALAN TERHADAP RETURN ON ASSET (STUDI KASUS PADA BANK UMUM SYARIAH 2011-2015)

terhadap ROA pada bank umum syariah periode 2011-2015.

3. Variabel CAR memiliki t-statistic sebesar 3,592959 dengan tingkat probabilitas sebesar 0,0009 yang berarti lebih kecil daria $(0,05)$, sehingga $\mathrm{H}_{01}$ ditolak. Kesimpulan yang dapat diperoleh adalah variabel CAR berpengaruh signifikan secara parsial terhadap ROA pada bank umum syariah periode 2011-2015.

\section{Uji F (Simultan)}

Berdasarkan hasil uji $F$, tingkat probabilitas (F-Statistic) sebesar 0,000000 yang berarti lebih keil dari a $(0,05)$, sehingga $\mathrm{H}_{01}$ ditolak dan $\mathrm{H}_{\mathrm{al}}$ diterima. Dapat disimpulkan bahwa variabel iBVAIC, GCG, dan CAR secara simultan berpengaruh signifikan terhadap ROA pada bank umum syariah periode 20112015.

\section{Pembahasan}

Pengaruh Intellectual Capital dengan iB-

VAIC Secara Parsial terhadap Return on

\section{Asset Pada Bank Umum Syariah}

Hasil penelitian ini menunjukkan variabel intellectual capital yang dihitung dengan menggunakan iB-VAIC berpengaruh signifikan secara parsial terhadap return on asset pada bank umum syariah di Indonesia. Hal tersebut dapat dilihat dari nilai probabilitas (tstatistic) yaitu sebesar 0,0000. Nilai signifikansi tersebut lebih kecil dari 0,05 sehingga $\mathrm{H}_{0 l}$ ditolak dan $\mathrm{Hal}$ diterima dan dapat disimpulkan bahwa variabel intellectual capital dengan iB-VAIC berpengaruh signifikan secara parsial terhadap return on asset pada bank umum syariah periode 2011-2015.

Hal ini menunjukkan bahwa intellectual capital dengan iB-VAIC mempunyai peran yang penting dalam meningkatkan return on asset bank umum syariah. Semakin tinggi nilai intellectual capital dengan iB-VAIC (Islamic Banking Value Added Intellectual Coefficient) pada Bank Umum Syariah (BUS) maka akan menciptakan nilai tambah atau value added bagi Bank Umum Syariah (BUS). Value added atau nilai tambah tersebut berupa keungulan bersaing yang dapat meningkatkan return on asset bank tersebut.

Hal ini menguatkan teori stakeholder yang telah dijelaskan oleh Ulum (2009: 6), yang menyatakan bahwa ketika manajer mampu mengelola organisasi secara maksimal, khususnya dalam upaya penciptaan nilai bagi perusahaan, maka itu artinya manajer telah memenuhi aspek etika dari teori ini. Penciptaan nilai (value creation) dalam konteks ini adalah dengan memanfaatkan seluruh potensi yang dimiliki perusahaan, baik karyawan (human capital), aset fisik (physical capital), maupun structural capital. Pengelolaan yang baik atas seluruh potensi ini akan menciptakan value added bagi perusahaan yang kemudian dapat mendorong kinerja keuangan perusahaan untuk kepentingan stakeholder. Hasil penelitian ini juga mendukung resource based theory yaitu pengelolaan sumber daya secara baik 
Fitriani, et al/Jurnal Ekonomi Syariah Teori dan Terapan Vol. 4 No. 7 Juli 2017: 560-575; PENGARUH KINERJA SUMBER DAYA MANUSIA, KINERJA MANAJEMEN, DAN KINERJA PERMODALAN TERHADAP RETURN ON ASSET (STUDI KASUS PADA BANK UMUM SYARIAH 2011-2015)

akan memberikan nilai tambah bagi perusahaan agar dapat bersaing dalam dunia bisnis.

Hasil penelitian ini mendukung hasil penelitian yang telah dilakukan oleh penelitian yang dilakukan oleh Ulum (2007) yang menyimpulkan bahwa intellectual capital berpengaruh signifikan positif terhadap kinerja perusahaan sekarang dan masa depan (ROA, ATO,dan GR). Penelitian ini juga mendukung penelitian yang telah dilakukan oleh Chen et al. (2005) dalam Ulum (2009:101) yang menunjukan bahwa apabila penggunaan dan pemanfaatan intellectual capital semakin baik maka dapat meningkatkan profitabilitas perusahaan, sehingga kinerja akan semakin baik. Oleh karena itu kemampuan perusahaan dalam menghasilkan laba dengan total aset yang dimiliki akan semakin meningkat apabila perusahaan dapat memaksimalkan kinerja intellectual capital.

Pengetahuan yang menjadi sumber daya perusahaan adalah pengetahuan yang melekat dan dimiliki oleh setiap orang dalam perusahaan yang dapat dimanfaatkan untuk kepentingan perusahaan. Sumber daya pengetahuan tersebut bersifat tidak nyata dan sering disebut dengan intangible asset atau intellectual capital. Sumber daya tersebut lebih berpotensi memberikan keunggulan bersaing daripada tangible resources (Nasih, 2012). Dalam menghadapi persaingan dewasa ini, pengetahuan memiliki peranan yang sangat penting. Sebagaimana telah dijelaskan dalam Al-Qur'an dalam surah Ar-Rahman ayat 33, yang berbunyi:

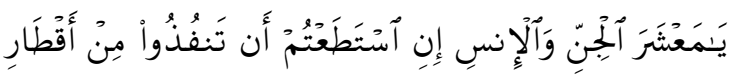

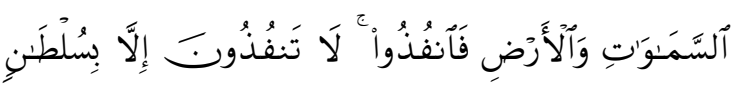

Ya- ma' syaral-jinni wal-insi inistata tum an tanfuzi ${ }^{-}$min aqtaris -samawāti wal-ardi fanfuzi, lā̄anfuziña illabisultān

"Hai jama'ah jin dan manusia, jika kamu sanggup menembus (melintasi) penjuru langit dan bumi, maka lintasilah, kamu tidak dapat menembusnya kecuali dengan kekuatan (Departemen Agama RI, 2010: 532).

\section{Pengaruh Kualitas Penerapan Good Corporate Governance Secara Parsial terhadap Return on Asset pada Bank Umum Syariah}

Hasil penelitian ini menunjukkan variabel kualitas penerapan GCG yang dihitung dari hasil self assessment pelaksanaan GCG yang berupa nilai komposit tidak memiliki pengaruh signifikan secara parsial terhadap return on asset pada bank umum syariah di Indonesia. Hal tersebut dapat dilihat dari nilai probabilitas (t-statistic).

Berdasarkan hasil pengolahan data diketahui bahwa tingkat probabilitas (t-statistic) yaitu sebesar 0,2890. Nilai signifikansi tersebut lebih besar dari 0,05 sehingga $\mathrm{H}_{01}$ diterima dan $\mathrm{Hal}$ ditolak. Menurut Permatasari dan Retno (2014), nilai komposit GCG tidak memilki pengaruh signifikan terhadap ROA bank umum syariah dapat diambil kesimpulan 
Fitriani, et al/Jurnal Ekonomi Syariah Teori dan Terapan Vol. 4 No. 7 Juli 2017: 560-575; PENGARUH KINERJA SUMBER DAYA MANUSIA, KINERJA MANAJEMEN, DAN KINERJA PERMODALAN TERHADAP RETURN ON ASSET (STUDI KASUS PADA BANK UMUM SYARIAH 2011-2015)

bahwa implementasi yang baik pada bank tidak menjamin dapat meningkatkan kinerja yang bank yang bersangkutan

Hasil penelitian ini mendukung hasil penelitian yang telah dilakukan oleh Permatasari dan Retno (2014). Hasil penelitian yang telah dilakukan oleh Permatasari dan Retno menunjukkan bahwa kualitas penerapan GCG tidak mempengaruhi kinerja bank. Sedangkan, hasil penelitian ini menolak hasil penelitian dari Tjondro dan Wilopo (2011) yang menyatakan bahwa GCG memiliki pengaruh yang positif signifikan terhadap profitabilitas perusahaan perbankan.

Kualitas penerapan GCG dapat dikatakan bahwa semakin kecil nilai komposit GCG dapat dikatakan semakin bagus. Artinya, semakin baik penerapan tata kelola bank maka semakin baik kinerja dari bank tersebut. Namun implementasi GCG yang bagus tidak menjamin peningkatan ROA bank seperti hasil dari penelitian ini yang menunjukkan bahwa kualitas penerapan GCG tidak berpengaruh signifikan secara parsial terhadap ROA bank umum syariah.

Sebagai contoh, Bank Victoria Syariah pada tahun 2014 memiliki nilai komposit sebesar 1,930 yang dapat dikatakan telah menerapkan implementasi GCG dengan baik. Namun ROA Bank Victoria Syariah pada tahun 2014 mengalami kerugian sebesar -0,0187. Kerugian ini diakibatkan karena terlalu berhati-hati dalam menyalurkan dana sehingga penyaluran dana tidak frontal yang kemudian menyebabkan penurunan laba. Selain itu, Bank Victoria Syariah pada tahun 2015 memiliki nilai komposit yang tinggi yaitu sebesar 3,000 yang dapat dikatan bahwa implementasi GCG pada Bank Victoria Syariah cukup baik. Akan tetapi ROA Bank Victoria Syariah pada tahun 2015 mengalami kerugian sebesar $-0,0236$. Penurunan ROA ini diakibatkan karena kurang berhati-hati dalam penyaluran dana, sehingga banyak pembiayaan bermasalah yang mengakibatkan penurunan laba.

Kualitas penerapan GCG merupakan mekanisme pengendalian kegiatan operasi perusahaan agar berjalan sesuai dengan mekanisme perusahaan. Melihat hasil penelitian diatas menunjukkan bahwa implementasi GCG yang baik bukan merupakan jaminan dalam meningkatkan ROA suatu Bank. Peningkatan ROA dipengaruhi oleh berbagai macam faktor, diantaranya adalah laba. Jika banyak BUS yang mengalami kerugian dalam periode penelitian ini serta kemungkinan ada faktor lain dan variabel yang lain yang tidak di teliti sehingga mengakibatkan penelitian ini tidak signifikan.

\section{Pengaruh Tingkat Kecukupan Modal Secara Parsial terhadap Return on Asset pada Bank Umum Syariah}

Hasil penelitian ini menunjukkan variabel tingkat kecukupan modal yang dihitung dengan menggunakan CAR memiliki pengaruh yang signifikan secara parsial terhadap ROA pada bank umum syariah di Indonesia. Hal tersebut dapat 
Fitriani, et al/Jurnal Ekonomi Syariah Teori dan Terapan Vol. 4 No. 7 Juli 2017: 560-575; PENGARUH KINERJA SUMBER DAYA MANUSIA, KINERJA MANAJEMEN, DAN KINERJA PERMODALAN TERHADAP RETURN ON ASSET (STUDI KASUS PADA BANK UMUM SYARIAH 2011-2015)

dilihat dari nilai probabilitas (t-statistic). Berdasarkan hasil pengolahan data diketahui bahwa tingkat probabilitas (tstatistic) yaitu sebesar 0,0009. Nilai signifikansi tersebut lebih kecil dari 0,05 sehingga $\mathrm{H}_{01}$ ditolak dan Hal diterima. Oleh karena itu, semain tingginya CAR dalam bank umum syariah maka semakin tinggi kemmapuan permodalan Bank dalam menjaga kemungkinan terjadinya risiko kerugian kegiatan usaha sehingga ROA bank umum syariah pun akan meningkat.

Hasil penelitian ini mendukung hasil penelitian yang telah dilakukan oleh Pasaribu dan Rosa (2011). Hasil penelitian yang telah dilakukan oleh Pasaribu dan Rosa menunjukkan bahwa tingkat kecukupan modal yang diproksikan oleh Capital Adequacy Ratio (CAR) memberikan pengaruh yang signifikan terhadap return on asset. Namun tidak sesuai dengan hasil penelitian dari Widyaningrum (2015). Hasil penelitian yang telah dilakukan Widyaningrum menunjukkan bahwa CAR tidak berpengaruh signifikan terhadap ROA.

CAR merupakan faktor yang penting bagi bank dalam rangka pengembangan usaha dan menampung kerugian serta mencerminkan kesehatan bank yang bertujuan untuk menjaga kepercayaan masyarakat kepada perbankan, melindungi dana masyarakat pada bank bersangkutan dan untuk memenuhi standar BIS. Faktor permodalan sangat penting dalam menjalankan kegiatan operasional bank dan untuk menunjang segala kebutuhannya, dengan kualitas pihak manajemen dalam pengelolaan kegiatan perbankan akan mendapatkan tingkat laba yang diharapkan. Dengan pengelolaan yang baik suatu bank akan terus meningkatkan modal dengan memperhatikan indikator kesehatan permodalan yaitu CAR, maka profitabilitas pun akan ikut meningkat (Pasaribu dan Rosa, 2011).

Dalam pelaksanaan suatu bisnis atau usaha pengelolaan sumber daya yang bagus serta tata kelola perusahaan yang bagus tanpa didukung dengan modal yang mencukupi dalam bisnis tersebut maka usaha atau bisnis tersebut tidak akan berjalan. Modal merupakan sesuatu yang sangat penting dalam suatu bank umum syariah. Tanpa modal Bank tidak akan dapat menjalankan kegiatan operasinya sehari-hari sehingga kepercayaan masyarakat dan juga untuk menunjang segala kebutuhannya.

Pengaruh Intellectual Capital dengan iBVAIC, Kualitas Penerapan GCG, dan Tingkat Kecukupan Modal Secara Simultan terhadap Return on Asset pada Bank Umum Syariah

Hasil penelitian ini menunjukkan bahwa intellectual capital dengan iBVAIC, kualitas penerapan GCG dan tingkat kecukupan modal berpengaruh signifikan secara simultan terhadap ROA. Hal tersebut dapat dilihat dari nilai probabilitas (F-statistic). Berdasarkan hasil pengolahan data diketahui bahwa tingkat probabilitas (F-statistic) yaitu sebesar 0,000000 . Nilai signifikansi tersebut 
Fitriani, et al/Jurnal Ekonomi Syariah Teori dan Terapan Vol. 4 No. 7 Juli 2017: 560-575; PENGARUH KINERJA SUMBER DAYA MANUSIA, KINERJA MANAJEMEN, DAN KINERJA PERMODALAN TERHADAP RETURN ON ASSET (STUDI KASUS PADA BANK UMUM SYARIAH 2011-2015)

lebih kecil dari 0,05 sehingga $\mathrm{H}_{01}$ ditolak dan Hal diterima.

Intellectual capital dengan iBVAIC (Islamic Banking Value Added Intellectual Coefficient), kualitas penerapan GCG dan tingkat modal yang dikelola dengan baik dan konsisten dapat meningkatkan return on asset suatu perusahaan. Hal ini menunjukkan bahwa intellectual capital yang dikelola secara efisien akan menunjukkan bahwa bank tersebut mampu mengelola sumber daya yang dimilikinya dengan baik, pengelolaan sumber daya yang baik akan meningkatkan kemampuan karyawannya sehingga kemampuan karyawan ini lah yang akan memberikan kontribusi kedalam perusahaan dalam peningkatan kinerja perusahaan dan akan tercapainya keunggulan kompetitif bagi perusahaan.

Perusahaan juga akan mampu bersaing jika memiliki manajemen yang bagus di dalamnya. Kualitas penerapan GCG adalah cara untuk mewujudkan manajemen yang bagus dalam suatu Bank. Pengaruh besar dari suatu kinerja perusahaan adalah perusahaan itu sendiri, bagaimana manajemen dapat mengelola suatu perusahaan tersebut dengan baik untuk tujuan utamanya. Dengan pengelolaan sumber daya pengetahun dengan baik dan juga didukung dengan kualitas pengelolaan manajemen yang bagus dalam suatu Bank jika tidak didukung dengan modal yang mencukupi maka perusahaan tersebut tidak akan berjalan. Karena modal merupakan sesuatu yang sangat penting dalam perkembangan dan kemajuan perusahaan. Modal juga digunakan untuk mendukung kegiatan dalam sehari-hari dalam rangka untuk meningkatkan kepercayaan masyarakat. Pengelolaan yang baik dalam suatu bank akan terus meningkatkan modal dengan memperhatikan indikator kesehatan permodalan yaitu CAR maka ROA pun akan ikut meningkat.

\section{Simpulan dan Saran}

\section{Simpulan}

Berdasarkan hasil penelitian dan juga pembahasan yang telah dilakukan mengenai maka simpulan yang dapat diambil adalah:

1. Intellectual Capital dengan iB-VAIC IIslamic Banking Value Added Intellectual Coefficient) berpengaruh signifikan secara parsial terhadap ROA Bank Umum Syariah periode 2011-2015.

2. Kualitas penerapan GCG tidak berpengaruh signifikan secara parsial terhadap ROA Bank Umum Syariah periode 2011-2015.

3. Tingkat kecukupan modal berpengaruh signifikan secara parsial terhadap ROA Bank Umum Syariah periode 2011-2015.

4. Intellectual Capital dengan iB-VAIC (Islamic Banking Value Added Intellectual Coefficient), kualitas penerapan GCG, dan tingkat kecukupan modal berpengaruh signifikan secara simultan terhadap ROA Bank Umum Syariah periode 2011-2015. 
Fitriani, et al/Jurnal Ekonomi Syariah Teori dan Terapan Vol. 4 No. 7 Juli 2017: 560-575; PENGARUH KINERJA SUMBER DAYA MANUSIA, KINERJA MANAJEMEN, DAN KINERJA PERMODALAN TERHADAP RETURN ON ASSET (STUDI KASUS PADA BANK UMUM SYARIAH 2011-2015)

Saran

Saran yang dapat diberikan dari penelitian ini adalah:

1. Bagi Bank Umum Syariah Hasil penelitian ini dapat digunakan sebagai sarana memperbaiki diri terkait dengan pengelolaan sumber daya pengetahuan, implementasi GCG dan tingkat kecukupan modal. Hasil penelitian ini memberikan indikasi bahwa IC yang dihitung dengan iB-VAIC kualitas penerapan GGC dan tingkat kecukupan modal dan ROA saling berhubungan. Tidak dipungkiri bahwa sumber daya pengetahuan merupakan lifeblood dalam keberhasilan suatu bank. Seharusnya keberadaan IC perlu diperhatikan dalam proses penciptaan nilai tambah suatu perusahaan, karena hasil yang diperoleh dalam penelitian ini menekankan bahwa intellectual capital berhubungan positif dengan ROA. Pengelolaan sumber daya pengetahuan yang baik dapat meningkatkan kemampuan karyawannya dalam pengimplementasian GCG dengan baik sehingga bank dapat memenuhi kewajiban penyediaan modal minimum. Namun, ketika suatu bank mengimplementasikan GCG dengan baik hendaknya diikuti dengan membaiknya financing yang berada dalam suatu bank, yang kemudian akan meningkatkan laba suatu bank yang berakibat pada peningkatan ROA bank.

2. Bagi Peneliti Selanjutnya

Bagi peneliti selanjutnya dapat memperluas sampel penelitian, dapat menambah jumlah periode penelitian agar mendapatkan hasil yang lebih baik, dan juga dapat menggunakan indikator lain dalam hal pengukuran kinerja bank syariah.

\section{Daftar Pustaka}

Bank Indonesia. 2009. Peraturan Bank Indonesia. (online), (http://www.bi.go.id, diakses 9 Agustus 2016).

Departemen Agama RI. 2010. Al-Qur'an ku Dengan Tajwid Blok Warna Disertai Terjemah. Jakarta: Lautan Lestari.

Ekowati, Serra dkk. 2012. Pengaruh Modal Fisik, Modal Finansial, dan Modal Intelektual terhadap Kinerja Perusahaan Pada Perusahaan Manufaktur Di Bursa Efek Indonesia. Jurnal Akuntansi Unsoed. Vol 1, No 1.

Ismail. 2011. Perbankan Syariah. Edisi Pertama. Jakarta: Kencana.

Marfuah dan Maricha Ulfa. 2014. Pengaruh Intellectual Capital Terhadap Profitabilitas, Produktivitas dan Pertumbuhan Perusahaan Perbankan. Jurnal EKBISI. Vol. IX, No. 1.

Muhammad. 2004. Manajemen Dana Bank Syari'ah. Edisi Pertama. Yogyakarta: Ekonisia.

Muneeza, Aishath dan Rusni Hassan. 2014. Shari'ah Corporate Governance: The Need For A Special Governance Code. International Journal of Business in Society. Vol. 14 No. 1, pp. 120-129.

Nasih, Moh. 2012. Manusia Sebagai Penentu Penciptaan Nilai dan Kinerja Perusahaan Perbankan di Indonesia. Jurnal Masyarakat, Kebudayaan dan Politik, Vol. 25 No. 4.

Otoritas Jasa Keuangan. 2016. Statistik Perbankan Syariah. (online), (http://www.ojk.go.id, diakses 13 November 2016).

Pasaribu, Hiras dan Rosa Luxita Sari. 2011. Analisis Tingkat Kecukupan modal dan Loan To Deposit Ratio Terhadap 
Profitabilitas. Jurnal Telaah \& Riset Akuntansi. Vol. 4 No. 2. Hal.114-125.

Permatasari, Ika dan Retno Novitasary. 2014. Pengaruh Implementasi Good Corporate Governance Terhadap Permodalan Dan Kinerja Perbankan Di Indonesia: Manajemen Risiko Sebagai Variabel Intervening. Jurnal Ekonomi Kuantitatif Terapan. Vol. 7 No. 1.

Rivai, Veithzal. 2009. Islamic Human Capital Dari Teorike Praktik Manajemen Sumber Daya Islami. Jakarta: PT Raja Grafindo Persada.

Sawarjuwono, Tjiptohadi dan Agustine Prihatin Kadir. 2003. "Intellectual Capital, Perlakuan, Pengukuran dan Pelaporan (sebuah Library Research)".Jurnal Akuntansi dan Keuangan. Vol.5, No.1. Mei 35-57.

Ståhle, Pirjo dkk. 2011. "Valve Added Intellectual Coefficient (VAIC): a critical analysis". Journal of Intellectual Capital.Vol.12 Iss 4 pp. 531-551.

Tjondro, David dan R. Wilopo. 2011. Pengaruh Good Corporate Governance (GCG) terhadap Profitabilitas dan Kinerja Saham Perusahaan Perbankan yang Tercatat di Bursa Efek Indonesia. Journal of Business and Banking.Vol 1, No 1.hlm 114.

Ulum, Ihyaul. 2007. Pengaruh Intellectual Capital terhadap Kinerja Keuangan Perusahaan Perbankan di Indonesia. Tesis di Publikasikan. Semarang: Program Pascasarjana Universitas Diponegoro.

2009. Intellectual Capital: Konsep dan Kajian Empiris. Yogyakarta: Graha llmu.

2013. "iB-VAIC: Model Pengukuran Kinerja Intellectual Capital Perbankan Syariah di Indonesia", Jurnal Inferensi (terakreditasi). Vol 7 No. 1, hlm 185-206. ISSN: 1978-7332.

Widyaningrum, Linda. 2015. Pengaruh CAR, NPF, FDR, Dan OER Terhadap ROA
Pada Bank Pembiayaan Rakyat Syariah Di Indonesia Periode Januari 2009 Hingga Mei 2014. JESIT. Vol. 2 No. 12.

Yuliana. 2015. Analisis Pengaruh Intellectual Capital, Struktur Kepemilikan dan Tingkat Kecukupan Modal Terhadap Kinerja Perusahaan. Naskah Publikasi. Surakarta: Universitas Muhammadiyah Surakarta. 